\title{
MOLECULAR CHARACTERIZATION OF STAPH. AUREUS AND SOME ENTERIC BACTERIA PRODUCING TOXINS IN MINCED MEAT SOLED IN PORT-SAID CITY MARKETS
}

\author{
GIHAN M.O. MOHAMMED ${ }^{1}$ and HANAN A. EL DAHSHAN ${ }^{2}$ \\ ${ }^{1}$ Department of Bacteriology, Animal Health Research Institute, Port-Said Branch \\ ${ }^{2}$ Department of Food Hygiene, Animal Health Research Institute, Port-Said Branch
}

Received: 24 August 2016; $\quad$ Accepted: 9 October 2016

\begin{abstract}
A total of 100 minced meat samples were collected from different butchers in Port-Said city for isolation and identification of Staph. aureus, Escherichia coli and Salmonella spp.. The results revealed that Staph. aureus, E. coli and Salmonella spp. could be detected in a percentage of $14 \%, 12 \%$ and $1 \%$ respectively from minced meat samples. Molecular characterizations of all isolated S. aureus, E. coli and Salmonella spp. were confirmed using 16S rRNA, phoA and invA, respectively by conventional PCR at 791 bp; 720 bp and 284 bp, respectively. Multiplex PCR was developed with specific primers for the detection of different enterotoxin genes (Sea, Seb, Sec, Sed and See) of Staph. aureus, (Stx1, Stx2, STa and lt) of E. coli and (stn) of Salmonella which may be considered a significant in food safety threat. The obtained results showed that the positive serotypes for enterotoxin genes were ( $\mathrm{Seb}$ in 3 isolates and Sed in one isolate) of Staph. aureus at 164 bp and 278 bp respectively; (Stx2 in 2 isolates and $S T a$ in 2 isolates) of E. coli at 779 bp and $229 \mathrm{bp}$, respectively. Conventional PCR is rapid methods for the confirmation of Staph. aureus, E. coli and Salmonella spp., while multiplex PCR is a useful technique for detection of enterotoxin genes. The public health hazards of this isolated organism, as well as recommended measures to improve quality status of minced meat were discussed.
\end{abstract}

Key words: Staph. aureus, E. coli and Salmonella spp., PCR, enterotoxin genes, minced meat.

\section{INTRODUCTION}

Minced meat that has been minced into fragments and contains less than $1 \%$ salt. Minced meat has an important role in human nutrition as they are desirable foodstuff (Biesalski, 2005). In a whole cut from an animal, the interior of the meat is essentially sterile, even before cooking; any bacterial contamination is on the outer surface of the meat. When meat is ground, bacterial contamination from the surface can be distributed throughout the meat. If ground beef is not well cooked all the way through, there is a significant chance that enough pathogenic bacteria will survive to cause illness. Food-borne illness is a major international health problem (Mensah et al., 2002 and Ayten et al., 2014).

Food-borne diseases coming from pathogenic bacteria have been of vital concern to public health. Staph. aureus; E. coli and Salmonella spp. are considered more frequent human pathogens. They are often simultaneously found in some contaminated food matrices, such as meat products (Leclerc et al., 2002). E. coli, is generally used as an indicator of fecal

Corresponding author: Dr. GIHAN M.O. MOHAMMED E-mail address: dr.gehanomer@yahoo.com

Present address: Department of Bacteriology, Animal Health Research Institute, Port-Said Branch pollution and some strains may cause severe diseases (Ahmed et al., 2007). Salmonella spp. and Staph. aureus remains a major cause of morbidity and mortality worldwide (Threlfall 2008 and Schreiber et al., 2011). Each year, millions of persons become ill from food-borne diseases, though many cases are not reported Centers for Disease Control and Prevention (1997). If you're getting mince from a butcher, it's likely to be made from cheaper cuts like chuck steak, from the front shoulders of the cow, and thin flank from the cow's belly. It will also probably include trimmings of meat from steaks, roasting joints and others. The butchers will also make sure that there's a percentage of fat in the mince because it needs a certain amount to give it moisture and flavor as it cooks. Food-borne pathogens such as bacteria or their toxins may lead to human disease when contaminated food is eaten. The source of contamination may vary but harmful bacteria are mostly responsible for causing gastrointestinal infections (Scallan et al., 2011). Food-borne illnesses and intoxications can occur due to the presence of certain bacteria such as Staph. aureus, E. coli and Salmonella spp. (Elmaliand Yaman 2005 and Tachbele et al., 2006). Microbial quality of minced meat as one of meat products plays an important role in increasing public health issue all over the world. During the last decades, there was a great improvement in hygienic technique for 
production of meat products with attention of a lot of consumers towards healthy nutrition Ahmedand Ismail, (2010).

Molecular detection methods based on PCR are increasingly accepted as alternatives to conventional cultural/ biochemical methods for the detection of bacterial contamination in food (De Boer and Beumer, 1999). PCR technique is considered as a sensitive detection method for specific pathogens. Multiplex PCR assay seems to be a useful technique for rapid and specific detection of pathogens in food and has been used for the control and prevention of food-borne epidemics (Kawasaki et al., 2009).

Due to the progressive increase in the incidence of food borne infections, there is an urgent need for control and/or prophylaxis for food poisoning outbreaks associated with meat products. It depends greatly on investigating the causative agents in mincedmeat, eliminating them to ensure food safety and to protect public health from microbial contamination. The aim of the current study was to determine the bacteriolological quality of minced meat obtained from different butchers in Port-Said city through determine the incidence of Staph. aureus, E. coli and Salmonella spp. with regarding to the public health as well as confirmed and determined some virulence genes by using PCR technique.

\section{MATERIALS AND METHODS}

1- Samples collection: One hundred samples of minced meat were randomly collected from different butchers in Port- Said city. Each sample was aseptically transported in ice-box to laboratory quicklyas soon as possible for detection of Staph. aureus, E. coli and Salmonella spp.

\section{Bacteriological examination:}

2.1- Isolation and Identification of Staph. aureus: Isolation of Staph. aureus was attempted according to ISO (1999). 10 gram of sample was homogenized with $90 \mathrm{ml}$ sterile enrichment broth peptone water and enriched for $24 \mathrm{hrs}$ at $37{ }^{\circ} \mathrm{C}$. A loopful of inoculum from enrichment broth was streaked on Baird Parker Agar (BPA) and incubated for 48 hours at $37^{\circ} \mathrm{C}$. Characteristic appearance of jet black colonies surrounded by a white halo was considered to be presumptive Staph. aureus. The pure cultures were streaked on Nutrient agar, incubated for 24 hours at $37^{\circ} \mathrm{C}$ for further characterized.

2.1.1- Morphological characteristics of Staph. aureus: The smear was prepared from the isolated culture and stained with Gram's stain. The stained smear revealed Gram positive, spherical cells arranged in irregular clusters resembling to bunch of grapes according to Cruickshank et al. (1975).

2.1.2- Biochemical examination: The biochemical tests were performed to confirm Staph. aureus using
Catalase test, Coagulase test, DNase test, Acetoin production, Oxidase test and D-mannitol fermentation according to Thaker et al. (2013).

2.2- Isolation and Identification of $\boldsymbol{E}$. coli: Isolation of E. coli was attempted according to Qunin et al. (2002). 10 gram of sample was homogenized with 90 $\mathrm{ml}$ sterile enrichment broth peptone water and incubated for $24 \mathrm{hrs}$ at $37^{\circ} \mathrm{C}$. A loopful from inoculated broth was streaked on the surface of Eosin methylene blue agar plate. Inoculated plate was incubated at $37^{\circ} \mathrm{C}$ for $24-48 \mathrm{hr}$. The pure cultures were streaked on Nutrient agar and were incubated for 24 hours at $37^{\circ} \mathrm{C}$ for further characterized.

2.2.1- Morphological characteristics of $E$. coli: according to (Qunin et al., 2002).

2.2.2- Biochemical examination: The biochemical tests of $\boldsymbol{E}$. coli using Oxidase test, Indole production, Methyl red, Voges Proskauer test, Utilization of citrate, hydrogen sulfide production on Triple Sugar Iron agar (TSI), Hydrolysis of urea and Sugar fermentation test according to (Qunin et al., 2002).

2.3-Isolation and Identification of Salmonella spp.: Isolation of Salmonella spp. was attempted according to ISO (2002).

\subsection{1- Morphological characteristics of Salmonella spp.: according to (Qunin et al., 2002).}

2.3.2-Biochemical examination: The biochemical tests were performed to confirm $\boldsymbol{E}$. coli using Oxidase test, hydrogen sulfide production on Triple Sugar Iron agar (TSI), Hydrolysis of urea and Lysine iron agar according to (Qunin et al., 2002).

3. Molecular characterization and detection of Staph. aureus, E. coli and Salmonella spp. enterotoxins genes:

The Staph. aureus, E. coli and Salmonella spp. isolated from minced meat samples were confirmed by PCR using (16S rDNA of Staph. aureus), (phoA of E. coli) and (invA of Salmonella spp.), also determining some enterotoxins genes using specific primers (Sea, Seb, Sec, See and Sed) for Staph. aureus, (Stx1, Stx2, STa and lt) for E. coli and (stn) for Salmonella spp.

3.1-DNA extraction: DNA extraction from samples was performed using the QIAamp DNA Mini kit (Qiagen, Germany, GmbH) with modifications from the manufacturer's recommendations. Briefly, $200 \mu \mathrm{l}$ of the sample suspension was incubated with $10 \mu \mathrm{l}$ of proteinase $\mathrm{K}$ and $200 \mu \mathrm{l}$ of lysis buffer at $56^{\mathrm{O}} \mathrm{C}$ for 10 min. After incubation, $200 \mu \mathrm{l}$ of $100 \%$ ethanol was added to the lysate. The sample was then washed and centrifuged following the manufacturer's recommendations. Nucleic acid was eluted with 150 $\mu \mathrm{l}$ of elution buffer provided in the kit. 
3.2-Oligonucleotide Primer: Primers are listed in

table (1)

Table 1: Primers sequences, target genes, amplicon sizes and cycling conditions.

\begin{tabular}{|c|c|c|c|c|c|c|c|c|}
\hline \multirow[t]{2}{*}{ Target gene } & \multirow[t]{2}{*}{ Primers sequences } & \multirow{2}{*}{$\begin{array}{c}\text { Amplified } \\
\text { segment (bp) }\end{array}$} & \multirow{2}{*}{$\begin{array}{c}\text { Primary } \\
\text { denaturation }\end{array}$} & \multicolumn{3}{|c|}{ Amplification (35 cycles) } & \multirow{2}{*}{$\begin{array}{c}\text { Final } \\
\text { extension }\end{array}$} & \multirow[t]{2}{*}{ Reference } \\
\hline & & & & $\begin{array}{c}\text { Secondar } \\
\text { denaturation }\end{array}$ & Annealing & Extension & & \\
\hline$\frac{\text { Staphylococcus }}{\text { Sea }}$ & $\begin{array}{c}\text { GGTTATCAATGTG } \\
\text { CGGGTGG } \\
\text { CGGCACTTTTTTC } \\
\text { TCTTCGG }\end{array}$ & 102 & $\begin{array}{l}94^{\circ} \mathrm{C} \\
5 \mathrm{~min} .\end{array}$ & $\begin{array}{c}94^{\circ} \mathrm{C} \\
30 \mathrm{sec} .\end{array}$ & $\begin{array}{c}50^{\circ} \mathrm{C} \\
45 \mathrm{sec} .\end{array}$ & $\begin{array}{l}72^{\circ} \mathrm{C} \\
45 \mathrm{sec} .\end{array}$ & $\begin{array}{l}72^{\circ} \mathrm{C} \\
10 \mathrm{~min} .\end{array}$ & $\begin{array}{l}\text { Mehrotra } \\
\text { et al., } \\
(2000)\end{array}$ \\
\hline Seb & $\begin{array}{c}\text { GTATGGTGGTGTA } \\
\text { ACTGAGC } \\
\text { CCAAATAGTGACG } \\
\text { AGTTAGG } \\
\end{array}$ & 164 & & & & & & \\
\hline Sec & $\begin{array}{c}\text { AGATGAAGTAGTT } \\
\text { GATGTGTATGG } \\
\text { CACACTTTTAGAA } \\
\text { TCAACCG }\end{array}$ & 451 & & & & & & \\
\hline Sed & $\begin{array}{c}\text { CCAATAATAGGA } \\
\text { GAAAATAAAAG } \\
\text { ATTGGTATTTTTTT } \\
\text { TCGTTC } \\
\end{array}$ & 278 & & & & & & \\
\hline See & $\begin{array}{l}\text { AGGTTTTTTCACA } \\
\text { GGTCATCC } \\
\text { CTTTTTTTTCTTCG } \\
\text { GTCAATC }\end{array}$ & 209 & & & & & & \\
\hline $\begin{array}{c}\text { Staphylococcus } \\
\text { I6S rRNA }\end{array}$ & $\begin{array}{c}\text { CCTATAAGACTGG } \\
\text { GATAACTTCGGG } \\
\text { CTTTGAGTTTCAA } \\
\text { CCTTGCGGTCG }\end{array}$ & 791 & $\begin{array}{l}94^{\circ} \mathrm{C} \\
5 \mathrm{~min} .\end{array}$ & $\begin{array}{c}94^{\circ} \mathrm{C} \\
30 \mathrm{sec} .\end{array}$ & $\begin{array}{c}55^{\circ} \mathrm{C} \\
45 \mathrm{sec} .\end{array}$ & $\begin{array}{r}72^{\circ} \mathrm{C} \\
45 \mathrm{sec} .\end{array}$ & $\begin{array}{c}72^{\circ} \mathrm{C} \\
10 \mathrm{~min} .\end{array}$ & $\begin{array}{l}\text { Mason } e t \\
\text { al., (2001) }\end{array}$ \\
\hline$\frac{E . c o l i}{\text { Stxl }}$ & $\begin{array}{l}\text { ACACTGGATGATC } \\
\text { TCAGTGG } \\
\text { CTGAATCCCCCTC } \\
\text { CATTATG }\end{array}$ & 614 & $\begin{array}{l}94^{\circ} \mathrm{C} \\
5 \mathrm{~min} .\end{array}$ & $\begin{array}{c}94^{\circ} \mathrm{C} \\
30 \mathrm{sec} .\end{array}$ & $\begin{array}{c}58^{\circ} \mathrm{C} \\
45 \mathrm{sec} .\end{array}$ & $\begin{array}{l}72^{\circ} \mathrm{C} \\
45 \mathrm{sec} .\end{array}$ & $\begin{array}{c}72^{\circ} \mathrm{C} \\
10 \mathrm{~min} .\end{array}$ & $\begin{array}{l}\text { Dipinetoet } \\
\text { al., (2006) }\end{array}$ \\
\hline Stx 2 & $\begin{array}{c}\text { CCATGACAACGG } \\
\text { ACAGCAGTT } \\
\text { CCTGTCAACTGAG } \\
\text { CAGCACTTTG }\end{array}$ & 779 & & & & & & \\
\hline STa & $\begin{array}{l}\text { GAAACAACATGA } \\
\text { CGGGAGGT } \\
\text { GCACAGGCAGGA } \\
\text { TTACAACA }\end{array}$ & 229 & $\begin{array}{l}94^{\circ} \mathrm{C} \\
5 \mathrm{~min} .\end{array}$ & $\begin{array}{c}94^{\circ} \mathrm{C} \\
30 \mathrm{sec} .\end{array}$ & $\begin{array}{c}57^{\circ} \mathrm{C} \\
45 \mathrm{sec} .\end{array}$ & $\begin{array}{l}72^{\circ} \mathrm{C} \\
45 \mathrm{sec} .\end{array}$ & $\begin{array}{c}72^{\circ} \mathrm{C} \\
10 \mathrm{~min} .\end{array}$ & $\begin{array}{l}\text { Leeet al. } \\
(2008)\end{array}$ \\
\hline$L T$ & $\begin{array}{c}\text { GGTTTCTGCGTTA } \\
\text { GGTGGAA } \\
\text { GGGACTTCGACCT } \\
\text { GAAATGT }\end{array}$ & 605 & & & & & & \\
\hline E. coli phoA & $\begin{array}{l}\text { CGATTCTGGAAAT } \\
\text { GGCAAAAG } \\
\text { CGTGATCAGCGGT } \\
\text { GACTATGAC }\end{array}$ & 720 & $\begin{array}{l}94^{\circ} \mathrm{C} \\
5 \mathrm{~min} .\end{array}$ & $\begin{array}{l}94^{\circ} \mathrm{C} \\
30 \mathrm{sec} .\end{array}$ & $\begin{array}{c}58^{\circ} \mathrm{C} \\
40 \mathrm{sec} .\end{array}$ & $\begin{array}{l}72^{\circ} \mathrm{C} \\
45 \mathrm{sec} .\end{array}$ & $\begin{array}{c}72^{\circ} \mathrm{C} \\
10 \mathrm{~min} .\end{array}$ & $\begin{array}{c}\text { Hu et al. } \\
\text { (2011) }\end{array}$ \\
\hline$\frac{\text { Salmonella }}{\text { Stn }}$ & $\begin{array}{c}\text { TTG TGT CGC TAT } \\
\text { CAC TGG CAA CC } \\
\text { ATT CGT AAC CCG } \\
\text { CTC TCG TCC }\end{array}$ & 617 & $\begin{array}{l}94^{\circ} \mathrm{C} \\
5 \mathrm{~min} .\end{array}$ & $\begin{array}{c}94^{\circ} \mathrm{C} \\
30 \mathrm{sec} .\end{array}$ & $\begin{array}{c}59^{\circ} \mathrm{C} \\
45 \mathrm{sec} .\end{array}$ & $\begin{array}{c}72^{\circ} \mathrm{C} \\
45 \mathrm{sec} .\end{array}$ & $\begin{array}{c}72^{\circ} \mathrm{C} \\
10 \mathrm{~min} .\end{array}$ & $\begin{array}{l}\text { Murugkar } \\
\text { et al. } \\
(2003)\end{array}$ \\
\hline$\frac{\text { Salmonella }}{\text { invA }}$ & $\begin{array}{c}\text { GTGAAATTATCGC } \\
\text { CACGTTCGGGCAA } \\
\text { TCATCGCACCGTC } \\
\text { AAAGGAACC }\end{array}$ & 284 & $\begin{array}{l}94^{\circ} \mathrm{C} \\
5 \mathrm{~min} .\end{array}$ & $\begin{array}{c}94^{\circ} \mathrm{C} \\
30 \mathrm{sec} .\end{array}$ & $\begin{array}{c}55^{\circ} \mathrm{C} \\
30 \mathrm{sec}\end{array}$ & $\begin{array}{c}72^{\circ} \mathrm{C} \\
30 \mathrm{sec}\end{array}$ & $\begin{array}{l}72^{\circ} \mathrm{C} \\
7 \mathrm{~min} .\end{array}$ & $\begin{array}{l}\text { Oliveira } e t \\
\text { al. (2003) }\end{array}$ \\
\hline
\end{tabular}


3.3-PCR amplification: Primers were utilized in a 25- $\mu 1$ reaction containing $12.5 \mu 1$ of Emerald Amp Max PCR Master Mix (Takara, Japan), $1 \mu l$ of each primer of 20 pmol concentrations, $4.5 \mu \mathrm{l}$ of water, and $6 \mu \mathrm{l}$ of DNA template. The reaction was performed in an applied biosystem 2720 thermal cycler. For multiplex PCR of enterotoxins, Primers were utilized in a 50- $\mu$ l reaction containing $25 \mu 1$ of Emerald Amp Max PCR Master Mix (Takara, Japan), $1 \mu \mathrm{l}$ of each primer of $20 \mathrm{pmol}$ concentrations, $5 \mu \mathrm{l}$ of water, and $10 \mu \mathrm{l}$ of DNA template. For dultiplex PCR of $E$. coli virulence genes (stx 1 and $s t x 2)$ or (STa and $L T)$, Primers were utilized in a 50- $\mu 1$ reaction containing $25 \mu \mathrm{l}$ of Emerald Amp Max PCR Master Mix (Takara, Japan), $1 \mu$ l of each primer of 20 pmolconcentration, $11 \mu \mathrm{l}$ of water, and $10 \mu \mathrm{l}$ of DNA template.

3.4-Analysis of the PCR Products: The products of PCR were separated by electrophoresis on $1.5 \%$ agarose gel in $1 \mathrm{x}$ TBE buffer at room temperature using gradients of $5 \mathrm{~V} / \mathrm{cm}$. For gel analysis, $20 \mu \mathrm{l}$ of the uniplex PCR products and $40 \mu \mathrm{l}$ of the multiplex PCR products were loaded in each gel slot. Gelpilot 100 bp plus DNA Ladder (Qiagen, Germany, GmbH) and generuler 100 bpladder were used to determine the fragment sizes. The gel was photographed by a gel documentation system (Alpha Innotech, Biometra) and the data was analyzed through computer software.

\section{RESULTS}

Table 2: Prevalence of Staph. aureus, E. coli and Salmonella spp. in mincedmeat samples (n=100).

\begin{tabular}{ccc}
\hline isolated organisms & No. & $\%$ \\
\hline Staph. aureus & 14 & $14 \%$ \\
\hline E. coli & 12 & $12 \%$ \\
\hline Salmonella & 1 & $1 \%$ \\
\hline
\end{tabular}

Table 3: Molecular characterization and some enterotoxin genes of Staph.aureus isolated from minced meat samples

\begin{tabular}{|c|c|c|c|c|c|c|c|c|c|c|c|c|}
\hline \multirow{3}{*}{$\begin{array}{l}\text { No. of tested } \\
\text { isolates }\end{array}$} & \multirow{2}{*}{\multicolumn{2}{|c|}{$16 S \mathrm{rRNA}$}} & \multicolumn{10}{|c|}{ enterotoxin genes } \\
\hline & & & \multicolumn{2}{|c|}{ Sea } & \multicolumn{2}{|c|}{ Seb } & \multicolumn{2}{|c|}{ Sec } & \multicolumn{2}{|c|}{ Sed } & \multicolumn{2}{|c|}{ See } \\
\hline & No. & $\%$ & No. & $\%$ & No. & $\%$ & No. & $\%$ & No. & $\%$ & No. & $\%$ \\
\hline 14 & 14 & 100 & - & 0.0 & 3 & 21.4 & - & 0.0 & 1 & 7.1 & - & 0.0 \\
\hline
\end{tabular}

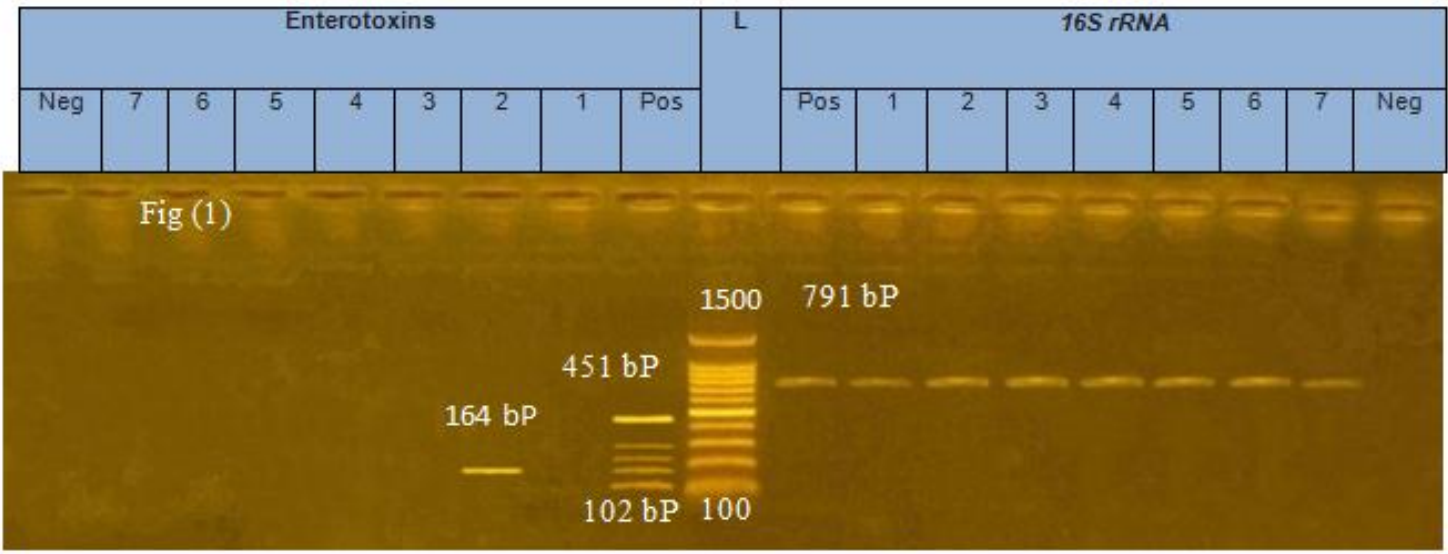




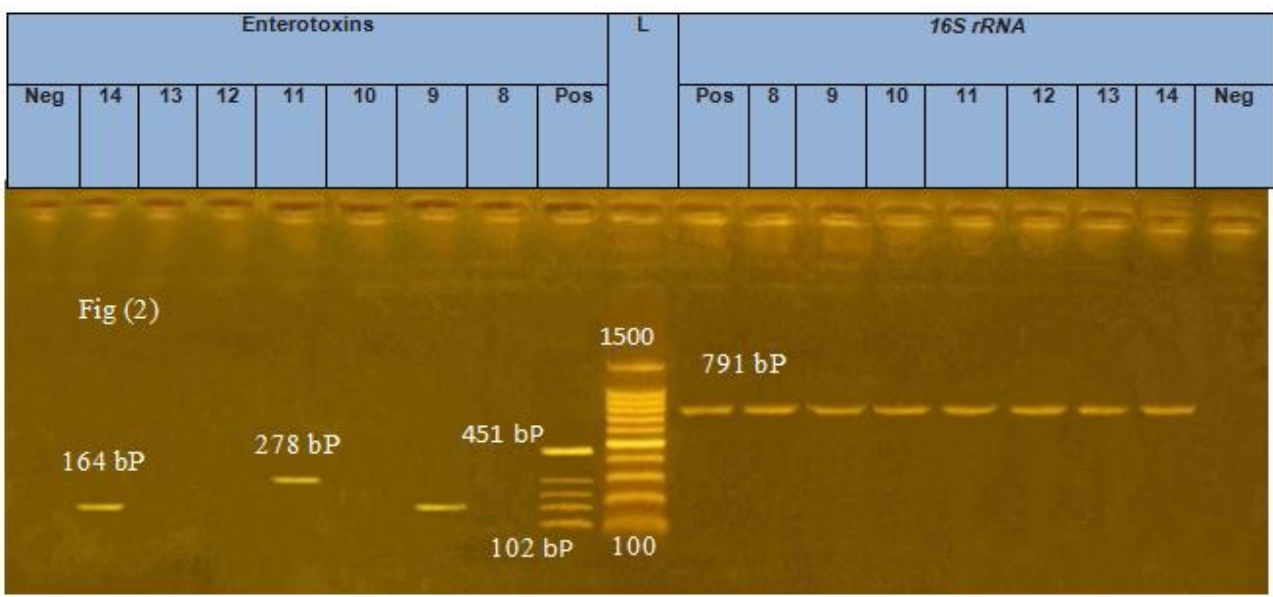

Fig. (1) \& Fig. (2): Agarose gel electrophoresis of PCR products after amplification of:

1- Staph. aureus 16Sr DNA gene. MWM-molecular weight marker (100 - 1500 bp DNA ladder), + control (Positive, Negative) + different strains of Staph. aureus (Staph. aureus16Sr DNA gene products at $791 \mathrm{bp}$ ).

2- Seagene (Sea gene products at $102 \mathrm{bp}$ ). 3- Seb gene (Seb gene products at $164 \mathrm{bp}$ ). 4- Sec gene (Sec gene products at $451 \mathrm{bp}$ ). 5- See gene (Sec gene products at $209 \mathrm{bp}$ ).

6- Sed gene (Sed gene products at $278 \mathrm{bp}$ ).

Table 4: Molecular characterization and some virulence genes of $E$. coli isolated from minced meat samples.

\begin{tabular}{|c|c|c|c|c|c|c|c|c|c|c|}
\hline \multirow{3}{*}{$\begin{array}{l}\text { No. of tested } \\
\text { isolates }\end{array}$} & \multirow{2}{*}{\multicolumn{2}{|c|}{ phoA }} & \multicolumn{8}{|c|}{ Enterotoxin genes } \\
\hline & & & \multicolumn{2}{|c|}{ Stx 1} & \multicolumn{2}{|c|}{ Stx 2} & \multicolumn{2}{|c|}{ STa } & \multicolumn{2}{|c|}{$l t$} \\
\hline & No. & $\%$ & No. & $\%$ & No. & $\%$ & No. & $\%$ & No. & $\%$ \\
\hline 12 & 12 & 100 & - & 0.0 & 2 & - & 2 & - & - & 0.0 \\
\hline
\end{tabular}

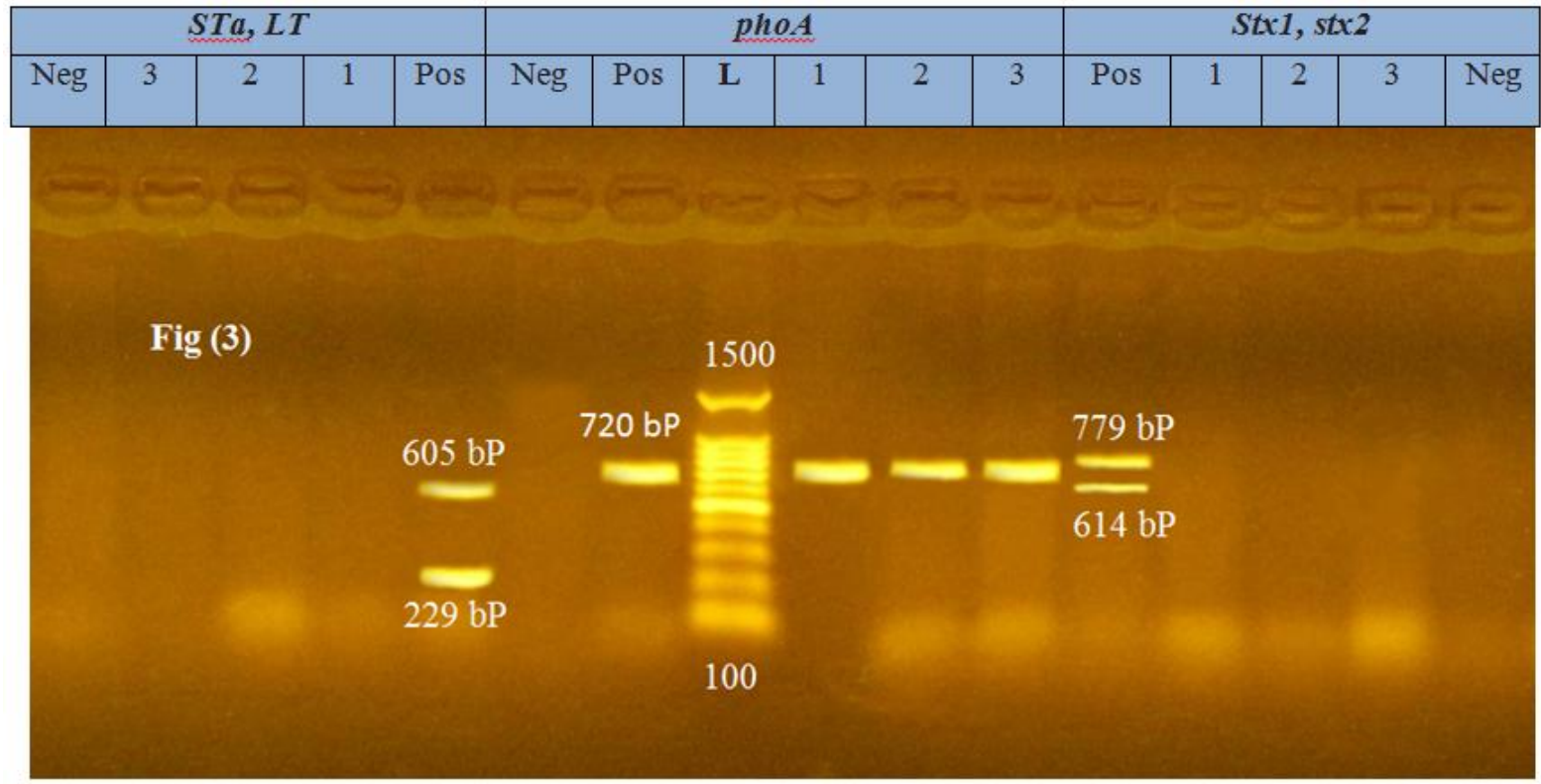



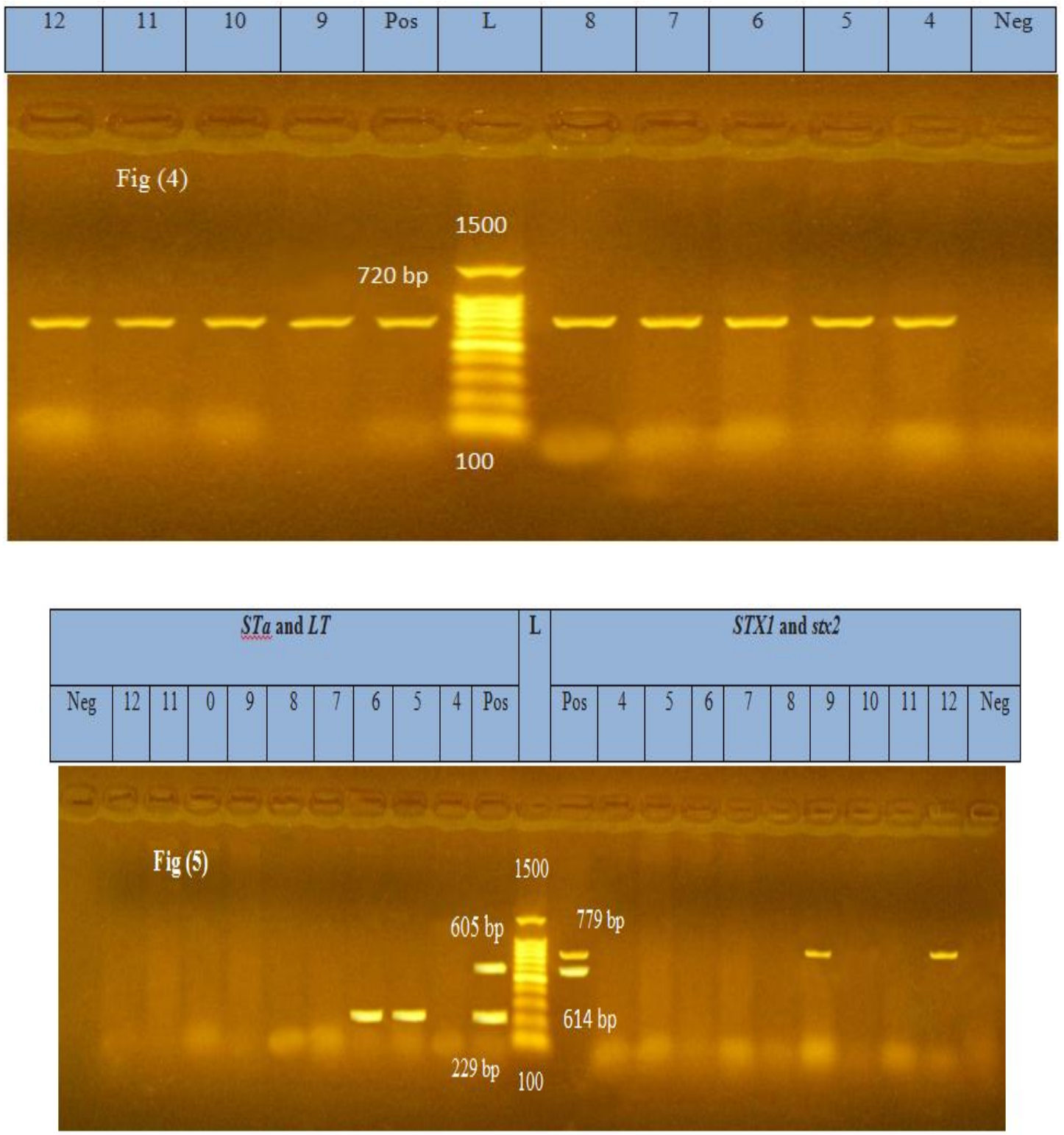

Fig. (3) \& (4) \& (5): Agarose gel electrophoresis of PCR products after amplification of:

1- E.coli PhoA gene. MWM-molecular weight marker (100 - 1500 bp DNA ladder), + control (Positive, Negative) + different strains of E.coli (E.coli PhoA gene products at 720bp).

2- Sta gene (Sta gene products at $229 \mathrm{bp})$. 3-LT gene ( $\boldsymbol{L T}$ gene products at $605 \mathrm{bp})$.

4- Stx 1 gene (Stx1gene products at 614 bp). 5- Stx 2 gene (Stx 2 gene products at $779 \mathrm{bp})$.

Table 5: Molecular characterization and some virulence genes of Salmonella Spp. Isolated from minced meat samples.

\begin{tabular}{cccccc}
\hline No. of tested isolates & & \multicolumn{1}{c}{ invA } & & \multicolumn{2}{c}{ Enterotoxin genes } \\
\cline { 3 - 6 } & & & & stn \\
\cline { 2 - 6 } & No. & $\%$ & No. & $\%$ \\
\hline 1 & 1 & 100 & - & 0.0
\end{tabular}




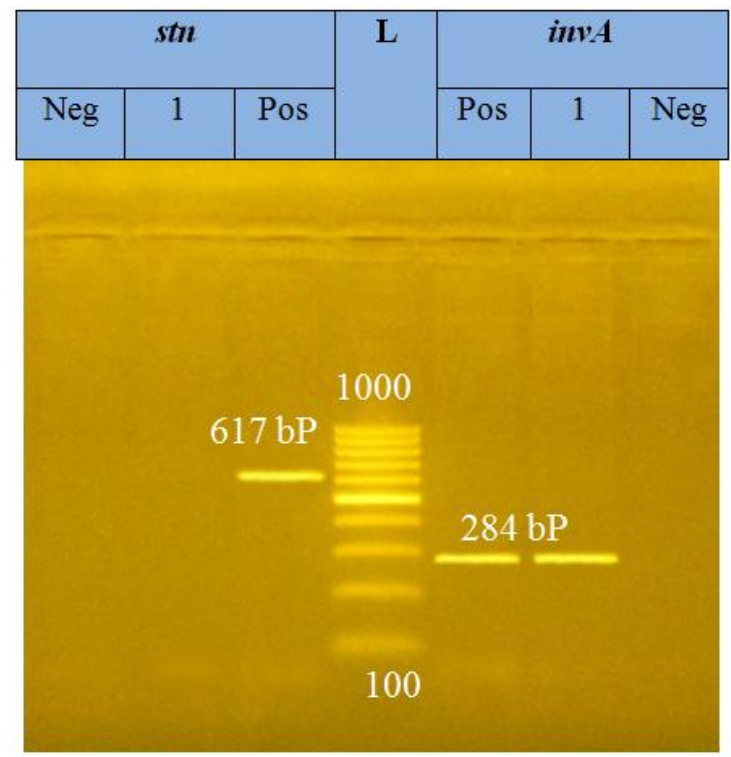

Fig (6): Agarose gel electrophoresis of PCR products after amplification of:

1- Salmonella spp. InvA gene. MWM-molecular weight marker (100 - 1000 bp DNA ladder), + control (Positive, Negative) + different strains of Salmonella (Salmonella spp. invA gene products at 284bp).

2- Stngene (stn gene products at $617 \mathrm{bp}$ ).

\section{DISCUSSION}

The present work was made in order to evaluate the prevalence of Staph. aureus, E. coli and Salmonella spp. among minced meat, also to confirm the isolated microbes and determined some enterotoxins genes characteristics of Staph. aureus, E. coli and Salmonella spp. using conventional PCR and multiplex PCR. So, a total of 100 minced meat samples showed bacterial contamination with species of the genera, Staph. aureus, E. coli and Salmonella spp. in percentages of $14 \%, 12 \%$ and $1 \%$, respectively in (Table 2). The presence of these isolates in the higher percentage in minced meat samples collected from different butchers in Port-Said city is an indication of unsatisfactory handling of minced meat and inadequate hygiene. Higher results were recorded by Sarah, (2014); Ezzat et al. (2014) and Raafat et al. (2011). The later isolated Staph. aureus, E. coli and Salmonella spp. in a percentages of $80 \%, 28 \%$ and $20 \%$, respectively from minced meat. The prevalence of $S$. aureus in different food products ranged from $5 \%$ to $100 \%$ (Adwan et al., 2005; Vázquez-Sánchez et al., 2012). The difference in the results may be attributed to difference in sampling procedure, locality, number of samples and difference in method used. Butthe prevalence of $E$. coli in different food ranged from $11 \%$ to $100 \%$ (Zhao et al., 2001; Ukut et al., 2010; Abdellah et al., 2013; Iyeret al., 2013 and Adeyanju and Ishola, 2014). While the prevalence of Salmonella in different food products ranged from $2 \%$ to $100 \%$ (Cohen et al., 2007; Aftab et al., 2012; Iyer et al.,
2013; Anihouvi et al., 2013; Adeyanju and Ishola, 2014).

Biochemical identified Staph. aureus, E. coli and Salmonella spp. (14, 12 and 1isolates, respectively) were submitted for molecular characterizations and confirmed by using (16S rRNA of Staph. aureus), (phoA of E. coli) and (invA of Salmonella spp.) by conventional PCR. The results proved that the isolates were Positive Staph. aureus (14 isolates), E. coli (12 isolates) and (one isolates) Salmonella spp. as recorded in tables (3, 4 and 5) and figures (1, 2, 3, 4 and 6). These results were agreement with those obtained by the conventional PCR assay with respective primers $16 S$ rRNA of Staph. aureus), (phoA of E. coli) and (invA of Salmonella spp.), suggesting PCR was able to confirm the Staph. aureus, E. coli and Salmonella infection (Manson et al., 2001; Hu et al., 2011 and Oliveira et al., 2003).

Determination of some enterotoxin genes ( $\mathrm{Sea}, \mathrm{Seb}$, Sec, Seeand Sed) of Staph. aureus, (Stxl, Stx2, STa and $l t$ ) of E. coli and (stn) of Salmonella spp. isolated from minced meat samples by multiplex PCR. Tables (3, 4 and 5) Figures (2 and 5) showed the positive serotypes for enterotoxin genes ( $\mathrm{Seb}$ in 3 isolates and Sed in one isolate) of S. aureus; (Stx2 in 2 isolates and $S T a$ in 2 isolates) of E. coli. None of the samples were positive for (Sea, Sec and See) of S. aureus, (Stxl and $l$ ) of E. coli and (stn) of Salmonella spp. These results were in agreement with those obtained by the multiplex PCR assay with respective primers (Sea, Seb, Sec, See and Sed) of S. aureus, (Stx1, Stx2, $S T a$ and $l t$ ) of E. coli and (stn) of Salmonella spp. 
(Mehrotra et al., 2000; Dipineto et al., 2006 and Lee et al., 2011 and Murugkar et al., 2003).

The negative results in PCR may be attributed to PCR based detection mainly depends on the purity and amount of the template DNA used (Estrada et al., 2007). The presence of PCR inhibitors in food samples and incomplete bacterial cell isolation lead to the production of false negative results in PCR based detection and the removal of PCR inhibitors, efficient bacterial cell isolation and efficient DNA extraction is important (Jeníkova et al., 2000). The variation in the presence of enterotoxin genes among different serotypes isolated from different sources of minced meat samples revealed that the mechanisms of pathogenesis depends mainly on the presence of different virulence factors not to the different serotypes. S. aureus, E. coli and Salmonella spp. from different food samples in different studies could be due in part to several factors including: differences in the reservoir, ecological origin of pathogenic strains, sensitivity of detection methods, detected genes, number of samples, type of sample, time of sampling and storage conditions (Zhao et al., 2001 and Adwan et al., 2005).

\section{CONCLUSION AND RECOMMENDATION}

From the obtained results, it can concluded that contamination by Staph. aureus, E. coli and Salmonella spp. were found in minced meat samples collected from different butchers in Port-Said city. The following suggestive measures should be considered to keep the examined products free from pathogens as possible:

- Routine microbiological examination should be adopted in minced meat factories, butchers shops, groceries and other food rendering outlet with a consequent certificate of nil presence food born bacteria.

- Hygienic awareness should be applied for personnel whom involved in handling and preparing of food at factories, home or restaurants.

- Careful handling and thorough cooking of minced meat, regardless of market source by the consumers is required to prevent food borne illness.

- Conventional and multiplex PCR is required as rapid, accurate and specific tool for isolated confirmation of isolated Staph. aureus, E. coli and Salmonella spp. and of detection of their enterotoxin genes.

\section{REFERENCES}

Abdellah, E.; Fouzia, R.F. and Bouchra, O. (2013): Prevalence and antibiogram study of Escherichia coli and Staphylococcus aureus in turkey meat in Morocco. Pharmaceutica Analytica Acta 4(9): 270.

Adeyanju, G.T. and Ishola, O. (2014): Salmonella and Escherichia coli contamination of poultry meat from a processing plant and retail markets in Ibadan, Oyo State, Nigeria. Springer Plus 3: 139.

Adwan, G.; Abu-Shanab, B. and Adwan, K. (2005): Enterotoxigenic Staphylococcus aureus in raw milk in the North of Palestine. Turkish Journal of Biology 29: 229-232.

Aftab, M.; Rahman, A.M.; Qureshi, M.S.; Akhter, S.; Sadique, U.; Sajid, U. and Zaman, S. (2012): Level of Salmonella in beef of slaughtered cattle at Peshawar. Journal of Animal and Plant Sciences 22(2): 24-27.

Ahmed, A.M. and Ismail, T.H. (2010): Improvement of the quality and shelf-life of minced beef mixed with soy protien by Sage (Saliva of ficinalis). African Journal of Food Science, 4: 330-334

Ahmed, W.; Tucker, J.; Bettelheim, KA.; Neller, R. and Katouli, M. (2007): Detection of virulence genes in Escherichia coli of an existing metabolic fingerprint database to predict the sources of pathogenic $E$. coli in surface waters. Water Res; 41:3785-91.

Anihouvi, D.G.H.; KAyodé, A.P.P.; Anihouvi, V.B.; Azokpota, P.; Kotchoni, S.O. and Hounhouigan, D.J. (2013): Microbial contamination associated with the processing of tchachanga, a roasted meat product. African Journal of Biotechnology 12(18): 2449-2455.

Aytenkimiran erdem1 duygu saglam2 didemozer 2 ezgiozcelik (2014): Microbiological quality of minced meat samples marketed in is tan bul. Veteriner fakultes idergisi; 25 (3), 67-70.

Biesalski, H.K. (2005): Meat as a component of a healthy diet. Are there any risks or benefits if meat is avoided in the diet. Meat Science; 70: 509-524.

Centers for Disease Control and Prevention (CDC) (1997): The Food-borne diseases active surveillance network, 1996. Morbidity and Mortality Weekly Report, 46: 258-261.

Cohen, N.; Ennaji, H.; Bouchrif, B.; Hassar, M. and Karib, H. (2007): Comparative study of microbiological quality of raw poultry meat at various seasons and for different slaughtering processes in Casablanca (Morocco). The Journal of Applied Poultry Research 16: 502508.

Cruickshank, R.; Duguid, J.P.; Marmion, B.P. and Swain, R.H.A. (1975): Medical Microbiology, $12^{\text {th }}$ ed., vol. II. Churchill Livingstone, Edinburg, London and New York.

De Boer, E. and Beumer, R.R. (1999): Methodology for detection and typing of foodborne microorganisms. International Journal of Food Microbiology 50: 119-130. 
Dipineto, L.; Santaniello, A.; Fontanella, M.; Lagos, K.; Fioretti, A. and Menna, L.F. (2006): Presence of Shiga toxin-producing Escherichia coli O157:H7 in living layer hens. Letters in Applied Microbiology 43 (2006) 293-295.

Elmall, M. and Yaman, H. (2005): Microbiological quality of raw meat balls: produced and sold in the eastern of Turkey. Pakistan. J. Nutr, 4 (4), 197-201.

Estrada, C.S.; Velasquez, L.D., Genaro, S.D. and Guzman, A.M. (2007): Comparison of DNA extraction methods for pathogenic Yersinia enterocolitica detection from meat food by nested PCR. Food Res. Inter., 40: 637-642.

Ezzat, M.E.; Zaki, E.M.S.; Mohammed, G.M.O. and Rabie, M.A. (2014): Molecular characterization of pathogenic $E$. coli isolated from meat and their products. Suez Canal Veterinary Medicine Journal, XIX(1):103-113.

Hu, Q.; Tu, J.; Han, X.; Zhu, Y.; Ding, C. and Yu, S. (2011): Development of multiplex PCR assay for rapid detection of Riemerella anatipestifer, Escherichia coli, and Salmonella enterica simultaneously from ducks. Journal of Microbiological Methods 87: 64-69.

ISO (1999): Microbiology of food and animal feeding stuffs - Horizontal method for the enumeration of coagulase-positive staphylococci (Staphylococcus aureus and other species) - Technique using rabbit plasma fibrinogen agar medium. International Standard ISO 6888-2, International Organization for Standardization, Geneva.

ISO (2002): Microbiology of food and animal feeding stuffs-Horizontal method for detection of Salmonella spp. ISO 6579 Organisation for Standardization.

Iyer, A.; Kumosani, T.; Yaghmoor, S.; Barbour, E.; Azhar, E. and Harakeh, S. (2013): Escherichia coli and Salmonella spp. in meat in Jeddah, Saudi Arabia. Journal of Infection in Developing Countries 7(11): 812-818.

Jeníkova, G.; Pazlarova, J. and Demnerova, $K$. (2000): Detection of Salmonella in food samples by the combination of immunomagnetic separation and PCR assay. Inter. J. Microbiol., 3:225-229.

Kawasaki, S.; Fratamico, P.M.; Horikoshi, N.; Okada, Y.; Takeshita, K.; Sameshima, T. and Kawamoto, S. (2009): Evaluation of a multiplex PCR system for simultaneous detection of Salmonella spp., Listeria monocytogenes, and Escherichia coli $\mathrm{O} 157: \mathrm{H} 7$ in foods and in food subjected to freezing. Foodborne Pathogens and Disease 6(1): 81-89.

Leclerc, V.; Dufour, B.; Lombard, B.; Gauchard, F.; Garin-Bastuji, B. and Salvat, G. (2002): Pathogens in meat and milk products: surveillance and impact on human health in France. Livest Prod Sci; 76: 195-202.

Lee, S.I.; Kang, S.G.; Kang, M.L. and Yoo, H.S. (2008): Development of multiplex polymerase chain reaction assays for detecting enterotoxigenic Escherichia coli and their application to field isolates from piglets with diarrhea. J Vet Diagn Invest 20:492-496.

Mason, W.J.; Blevins, J.S.; Beenken, K.; Wibowo, N.; Ojha, N. and Smeltzer, M.S. (2001): Multiplex PCR protocol for the diagnosis of staphylococcal infection. Journal of clinical microbiology, 39(9): 3332-3338.

Mehrotra, M.; Wang, G. and Johnson, W.M. (2000): Multiplex PCR for Detection of Genes for Staphylococcus aureus Enterotoxins, Exfoliative Toxins, Toxic Shock Syndrome Toxin 1, and Methicillin Resistance. Journal of Clinical Microbiology; 38(3).

Mensah, P.; Yeboah-Manu, D.; Owusu-Darko, K.; and Ablordey, A. (2002): Street foods in Accra, Ghana: how safe are they? Bulletin of the World Health Organization, 80: 546-553.

Murugkar, H.V.; Rahman, H. and Dutta, P.K. (2003): Distribution of virulence genes in Salmonella serovars isolated from man and animals. Indian J Med Res., 117:66-70.

Olivera, S.D.; Rodenbusch, C.R.; Ce, M.C.; Rocha, S.L.S. and Canal, C.W. (2003): Evaluation of selective and non selective en-richment PCR procedures for Salmonella de-tection. Lett. Appl. Microbiol., 36: 217-221.

Quinn, p.; Markey, B.; Carter, M.; Donelly, W. and Leonard, F. (2002): Veterinary microbiology, Microbial Disease. Black Well Science: 26-36.

Raafat, H.; Sohaila, F.H.A.; Ashraf, M.A.; Moemen, A.M and Khalid, I.E. (2011): Detection and identification of Salmonella species in minced beef and chicken meats by using Multiplex PCR in Assiut city. Veterinary World, 4 (1): 511.

Sarah, M.M.A. (2014):Molecular characterization of Staphylococcus aureus isolated from meat, milk and their products. M.V. Sc. Thesis, (Bacteriology, Immunology and Mycology) Faculty of Veterinary Medicine. Suez Canal University.

Scallan, E.; Griffin, P.M.; Angulo, F.J.; Tauxe, R.V. and Hoekstra, R.M. (2011): Foodborne illness acquired in the United States-unspecified agents. Emerg Infect Dis.17:16-27.

Schreiber, M.P.; Chan, C.M. and Shorr, A.F. (2011): Bacteremia in Staphylococcus aureus pneumonia: outcomes and epidemiology. J. Crit Care; 26: 395-401.

Tachbele, E.; Erku, W.; Gebre-Michael, T. and Ashenafi, M. (2006): Cockroach-associated food-borne bacterial pathogens from some hospitals and restaurants in Addis Ababa, 
Ethiopia: Distribution and antibiograms. J Rural Trop Public Health, 5, 34-41.

Thaker, H.C.; Brahmbhatt, M.N. and Nayak, J.B. (2013): Isolation and identification of Staphylococcus aureus from milk and milk products and their drug resistance patterns in Anand, Gujarat. Vet. World, 6 (1): 10-13.

Threlfall, E.J. (2008): Salmonella. In: Heggenhougen $\mathrm{K}$, Quah S, editors. International encyclopedia of public health. Amsterdam: Elsevier: 63947.

Ukut, O.E.; Okonko, I.O.; Ikpoh, I.S.; Nkang, A.O.; Udeze, A.O.; Babalola, T.A.; Mejeha, O.K. and Fajobi, E.A. (2010): Assessment of bacteriological quality of fresh meats sold in Calabar metropolis, Nigeria. Electronic
Journal of Environmental, Agricultural and Food Chemistry 9(1): 89-100.

Vázquez-Sánchez, D.; López-Cabo, M.; SaáIbusquiza, $P$. and Rodríguez-Herrera, J.J. (2012): Incidence and characterization of Staphylococcus aureusin fishery products marketed in Galicia (Northwest Spain). International Journal of Food Microbiology 157(2): 286-296.

Zhao, C.; Ge, B.; De Villena, J.; Sudler, R.; Yeh, E.; Zhao, S.; White, D.G.; Wagner, D. and Meng, J. (2001): Prevalence of Campylobacter spp., Escherichia coli, and Salmonella serovars in retail chicken, turkey, pork, and beef from the Greater Washington, D.C., area. Applied and Environmental Microbiology 67(12): 54315436.

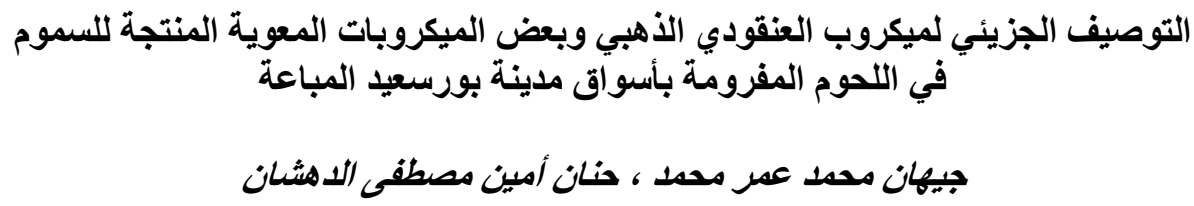

Email: dr.gehanomer@yahoo.com Assiut University web-site: www.aun.edu.eg

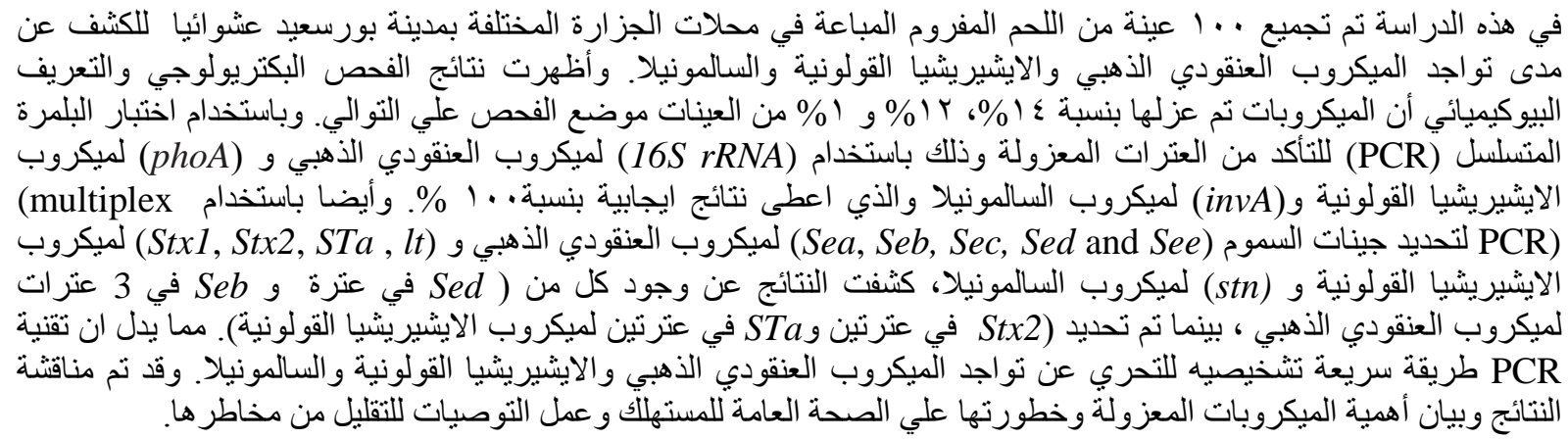

